\title{
Micronutrients Intake and Mathematics Achievement among Primary School Children in Magelang, Central Java
}

\author{
Romiza Arika1), Sapja Anantanyu²), Yulia Lanti Retno Dewi3) \\ ${ }^{1)}$ Masters Program in Nutrition, Universitas Sebelas Maret \\ 2)Doctoral Program in Community Development and Empowerment, Universitas Sebelas Maret \\ 3)Department of Nutrition, Faculty of Medicine, Universitas Sebelas Maret
}

\section{ABSTRACT}

Background: Micronutrient deficiency in school children is estimated at more than 2 million children. Deficiency of micronutrients causes damage to the physical functioning of children, impaired cognitive function, learning processes that are less than optimal, and poor academic performance. This study aimed to analyze the relationships between iodine, iron, zinc intake, and math achievement primary school children.

Subjects and Method: This was an observational analytic study with a cross sectional design. The study was conducted in four elementary schools in Pakis, Magelang, Central Java, from March to April 2019. A sample of 177 students was selected by simple random sampling. The dependent variable was math achievement. The independent variables were iodine, iron, and zinc intakes. The data were collected by question- naire and analyzed by a multiple linear regression.

Results: Iodine intake $(b=0.02 ; 95 \% \mathrm{CI}=0.01$ to $0.03 ; \mathrm{p}=0.001)$ and zinc intake $(\mathrm{b}=0.23 ; 95 \%$ $\mathrm{CI}=0.04$ to $0.41 ; \mathrm{p}=0.017)$, and iron intake $(\mathrm{b}=$ $0.08 ; 95 \% \mathrm{CI}=-0.01$ to $0.17 ; \mathrm{p}=0.052)$ increased math achievement in primary school children. Conclusion: Iodine intake, zinc intake, and iron intake increase math achievement in primary school children.

Keywords: iodine, zinc, and iron, math achievement, primary school children

\section{Correspondence:}

Romiza Arika. Masters Program in Nutrition, Universitas Sebelas Maret, Jl. Ir. Sutami 36A, Surakarta 57126, Central Java. Email: romizaarika652@gmail.com.Mobile: +6289506237763.

Cite this as:

Arika R, Anantanyu S, Dewi YLR (2020). Micro Nutrients Intake and Math Achievement in Primary School Children in Magelang, Central Java. J Matern Child Health. 5(2): 182-192.

https://doi.org/10.26911/thejmch.2020.05.02.08

Journal of Maternal and Child Health is licensed under a Creative Commons Attribution-Non Commercial-Share Alike 4.o International License.

\section{BACKGROUND}

Micronutrient deficiencies occur in school children with a percentage of more than 2 million children worldwide (Wang et al., 2017). Deficiencies in micronutrients cause damage to physical functioning of children, impaired cognitive function, learning processes that are less than optimal, and poor academic performance (Eilander et al., 2010). Balanced nutrition is very important for school children because school age is a period of physical growth and development, changes and adjustments to school activities, as well as for cognitive function (Kim and Kang, 2017). Adequate nutritional intake is beneficial for healthy brain function, learning processes and academic abilities (Ford et al., 2018). Optimal brain function is one of the requirements for efficient academic ability and having a more organized behavior to be able to take lessons in school (Bryan et al., 2004).

Perfect brain development occurs at the age of 7 years and the development of cognitive function can be increased until the age of 15 years with adequate iodine intake 
(Murcia et al., 2018). For school-age children, this period is the stage where motor and physical abilities develop, children begin to be aware of themselves and the world around and try to achieve independence, social adaptation, development and learning progress (Stiles and Jernigan, 2010). Cognitive disorders can interfere with orientation, language, motor function, memory, attention, and psychomotor speed (Pratiwi et al., 2019).

Iodine Deficiency Disorders (IDD) is one of the micronutrient issues of concern to WHO. Iodine deficiency occurs in 130 countries in the world and iodine deficiency in school children is estimated to reach $25 \%$ (Carvalho et al., 2018). Iodine deficiency can cause central nervous system development and brain damage, psychomotor disorders and Intelligent Quotient (IQ) deficits (Purnamasari et al., 2015).

Iodine deficiency is a common cause of brain damage in childhood that can be prevented if appropriate steps are taken early (Chen et al., 2017). Low iodine intake in the long run will have an IQ deficit of 50 points and infants born in endemic areas of IDD risk an IQ deficit of 13.5 points (Bougma et al., 2013). World Health Organization (WHO) recommends an optimal iodine intake for children aged 6-12 years is $120 \mu \mathrm{g}$ per day to prevent iodine deficiency and thyroid dysfunction (Koukkou et al., 2017).

Studies suggest that other micronutrient deficiencies such as iron adversely affect the learning process at school, and low iron intake is correlated with low math scores in female students (Fiorentino et al., 2018). Other studies have shown that increasing iron intake through food fortification can improve school academic performance (Soleimani and Abbaszadeh, 2011).

Low iron intake affects motor development in the early stages of life and disrupts cognitive function in childhood due to iron deficiency altering morphological, neu- rochemical, and interactive bioenergy processes such as oligodendrocyte wrapper for myelination, monoamine synthesis in the striatum that affects dopamine metabolism, and neuronal and glial energy metabolism in the hippocampus (Walker et al., 2007). Studies shows that children who have adequate iron intake have better language skills and show that iron affects perceptual and visual abilities (Allen et al., 2017).

Cognitive function and academic ability of school children are also influenced by other micronutrients, namely adequate zinc intake. Zinc is the second messenger in the body's immune cells and the free zinc levels in intracellular function in the activation of nerve signals (Wilsonet al., 2012). Adequate zinc intake can also increase body immunity so that children do not easily experience diarrhea (Hirano et al., 2008). Diarrhea at the age of school children can affect the development, growth and education of children because it can occur several times (Kartikaet al., 2019). Diarrhea also increases the incidence of other micronutrient deficiencies in children (Zicofet al., 2018).

Zinc deficiency can inhibit development through damage of more than 200 enzymes related to Ribonucleic acid (RNA) and Deoxyribonucleic acid (DNA) synthesis, regulation of N-methyl-D-aspartate (NMDA) receptors in the hippocampus, and several functions of brain mechanisms and structures (Benton, 2010). Previous studies reported that adequate zinc intake can improve cognitive function in children aged 6-9 years (Hesset al., 2009). Combination of zinc intake with other adequate micronutrients has a better effect than just zinc intake which is adequate (Prasad, 2013).

A cross-sectional study states that children with low focus and concentration experience zinc deficiency (Arnold and Disilvestro, 2005). The main factor contributing to zinc deficiency is the high intake of phy- 
tate-containing proteins especially in developing countries (Prasad, 2013).

Magelang Regency has a high altitude geographical condition that allows the area to be at risk of lack of iron, iodine and zinc intake because it is an endemic area of IDD that causes a lack of mineral reserves in the soil and difficult to obtain marine products (BPS, 2018b). One of the districts located high above sea level is Pakis District with a height of 841 meters above sea level (BPS, 2018a). This shows that public awareness about the importance of iodine in the prevention of IDD is still lacking. Based on this, this study was conducted to look at the intake of micronutrients in school children and their relationship with learning achievement.

\section{SUBJECTS AND METHOD}

\section{Study Design}

This study was an analytic observation study with a cross sectional design. The study was conducted in Pakis, Magelang, Central Java, from March 20 to April 11, 2019.

\section{Population and Sample}

The source population in this study is children aged 6-12 years who are elementary school students' grades 1-6 in Pakis District, Magelang. The target population in this study is children aged 6-12 years elementary school students' grades 1-6. Sample inclusion criteria in this study was to stay at the study site for at least 6 months and the exclusion criteria were children not attending school, seafood allergies, suffering from infectious diseases and getting extra tutoring outside of school subjects. A sample of 177 subjects was obtained through simple random sampling.

\section{Study Variables}

The dependent variable was math achievement. The independent variables were iodine, iron, and zinc intake.

4. Operational Definition of Variables Micronutrient intake in this study was iodine intake, iron intake, zinc intake and vitamin A intake. Assessment of micronutrient intake was carried out by nutritionist enumerators. The instrument used was a 24-hour form food recall and interpreted with the application Nutrisurvey 2007. Population intake levels were said to be adequate if micronutrient intake was $\geq 77$ percent of the RDA and said to be inadequate if the level of micronutrient intake was $<77$ percent of RDA. The measurement scale used is continuous data.

\section{Iodine intake}

Iodine intake is the amount of iodine intake consumed in a day (24 hours) that is absorbed from food sources of iodine. The need for iodine intake for primary school children aged 6-12 years based on the 2013 nutritional adequacy ratio (NAR) is $120 \mu \mathrm{g}$.

\section{Iron intake}

Iron intake is the amount of iron intake consumed in a day (24 hours) absorbed from food sources of iron. The need for iron intake of primary school children based on the 2013 RDA is $9 \mathrm{mg}$ (age 6 years), $10 \mathrm{mg}$ (ages 7-9 years), $13 \mathrm{mg}$ (ages 10-12 years, boys) and 20 mg (ages 10-12) year, female).

\section{Zinc intake}

Zinc intake is the amount of zinc intake consumed in a day (24 hours) that is absorbed from the food source of zinc. The need for zinc intake of primary school children based on the 2013 NAR is $5 \mathrm{mg}$ (age 6 years), $11 \mathrm{mg}$ (ages 7-9 years), $14 \mathrm{mg}$ (ages 10-12 years, man) and $13 \mathrm{mg}$ (ages 10-12 years, woman). Academic ability is the result of learning as measured by the value of the midterm exam in Semester II in mathematics. Collection of exam scores is obtained from secondary data from homeroom teachers. The measurement scale used is continuous data.

\section{Study Instruments}

Micronutrient intake data was obtained using a 3x24 hour food recall form. Academic ability is obtained by collecting midterm exam grades in mathematics with a form that contains the names of students in grades 1-6 
elementary school and the value of these subjects.

\section{Data Analysis}

Univariate analysis was performed to determine the frequency distribution of subject characteristics. Bivariate analysis was performed to determine the relationship between academic ability with the independent variables iodine intake, iron intake and zinc intake using the Pearson correlation. Multivariate analysis was performed using linear regression.

\section{Research Ethics}

Research ethics was conducted for this study, including informed consent, anonymity, and confidentiality. Research ethics was obtained from research ethics committee in Faculty of Medicine, Universitas Sebelas Maret, Surakarta, Central Java, with number 440/UN27.06/KEPK/2019.

\section{RESULTS}

\section{Univariate analysis}

Univariate analysis was performed to explain the frequency distribution of the characteristics of study subjects. The results of the analysis can be seen in Table 1.

Table 1. Univariate analysis (continuous data)

\begin{tabular}{lccccc}
\multicolumn{1}{c}{ Variables } & n & Mean & SD & Min. & Max. \\
\hline Age (year) & 177 & 9.14 & 1.78 & 6 & 12 \\
Iodine intake $(\mu \mathrm{g})$ & 177 & 134.50 & 105.32 & 12.7 & 427.56 \\
Iron intake $(\mathrm{mg})$ & 177 & 11.46 & 13.72 & 4.70 & 183 \\
Zinc intake $(\mathrm{mg})$ & 177 & 8.60 & 6.43 & 2.60 & 88.90 \\
Math score & 177 & 63.85 & 0.63 & 34 & 98 \\
\hline
\end{tabular}

Table 1 shows univariate results in which the study subjects had an average age of 9 years with the youngest age being 6 years and the oldest was 12 years. The subject iodine intake variable had a mean of $134.50 \mu \mathrm{g}$ per day with the lowest intake being $12.7 \mu \mathrm{g}$ per day and the highest intake was $427.56 \mu$ ger day.

Subject iron intake had a mean of 11.46 mg per day with the lowest intake being 4.70 mg per day and the highest intake was 183 mg per day. The subjects' zinc intake had a mean $8.60 \mathrm{mg}$ per day with the lowest intake being $2.60 \mathrm{mg}$ per day and the highest intake was $88.90 \mathrm{mg}$ per day. Subject's academic ability of the average mathematical value is 63.85 with the lowest mathematical value is 34 and the highest value is 98 .

\section{The result of bivariate analysis}

Table 2 shows the relationship between iodine intake, iron intake and zinc intake of primary school children with the results of mathematical scores.

Table 2. Correlations between iodine intake, iron intake, zinc intake, iron intake, and math achievement

\begin{tabular}{lcc}
\hline \multicolumn{1}{c}{ Independent Variable } & Correlation coefficient (r) & p \\
\hline Iodine intake & 0.25 & 0.001 \\
Iron intake & 0.16 & 0.031 \\
Zinc intake & 0.17 & 0.020 \\
\hline
\end{tabular}

Table 2 shows that iodine intake $(\mathrm{r}=0.25 ; \mathrm{p}=$ $0.001)$, iron intake $(\mathrm{r}=0.16 ; \mathrm{p}=0.031)$ and zinc intake $(\mathrm{r}=0.17 ; \mathrm{p}=0.020)$ school children are positively related to the results of mathematics scores and are statistically significant.

3. The result of multilevel analysis

Multivariate analysis was performed using 
Arika et al./Micro Nutrients Intake and Math Achievement in Primary School

the linear regression method. Multivariate intake) with the dependent variable is the explains the relationship of independent varimathematical value.

ables (iodine intake, iron intake, and zinc

Table 3 Analysis of multiple linear regression on the relationships between iodine intake, iron intake, zinc intake, and math achievement

\begin{tabular}{lcccc}
\hline \multirow{2}{*}{ Independent Variable } & \multirow{2}{*}{$\mathbf{b}$} & \multicolumn{2}{c}{ (95 \%) CI } & p \\
\cline { 3 - 4 } & & Lower Limit & Upper Limit & 0.001 \\
Iodine intake & 0.02 & 0.01 & 0.03 & 0.052 \\
Iron intake & 0.08 & -0.01 & 0.17 & 0.017 \\
Zinc intake & 0.23 & 0.04 & 0.41 & \\
n observation $=177$ & & & & \\
R squared $=17.5 \%$ & & & & \\
$\mathrm{p}=<0.001$ & & & & \\
\hline
\end{tabular}

The analysis results in Table 3 show that there is a statistically significant relationship between iodine intake and zinc intake with mathematical values. The analysis showed that there was a positive relationship between iodine intake $(b=0.02 ; 95 \% \mathrm{CI} 0.01$ to 0.03; $\mathrm{p}=0.001)$ and zinc intake $(\mathrm{b}=0.23$; 95\% CI $=0.04$ to $0.41 ; \mathrm{p}=0.017$ ) and academic ability of school children in counting. Iodine intake and zinc intake have very weak strengths in increasing the math scores of elementary school children. R squared values indicate the contribution of iodine intake and $17.5 \%$ vitamin $\mathrm{A}$ intake with a mathematical value and another $82.5 \%$ obtained by other factors outside the independent variable.

\section{DISCUSSION
1. The relationship between iodine intake and math achievement in primary school children}

Iodine is a micronutrient needed by the body to synthesize thyroid hormone and is essential for growth especially for neurological development (Andersson et al., 2012).

Almost all food sources have very low or even iodine content, but the best sources of iodine are seafood and animal dairy products (Campbell et al., 2012). Inadequate intake of iodine chronically can reduce a number of cognitive abilities and decrease intelligence (Bath et al., 2013). Moderate levels of iodine deficiency can also cause growth disorders (Beckford et al., 2017).

In some individuals who have a history or are experiencing thyroid disorders, even a slight increase in iodine intake can trigger thyroid disorders (Emder and Jack, 2011). Daily iodine intake should not exceed 500 $\mu \mathrm{g} /$ day, especially in countries that have a history of iodine deficiency (Gordon et al., 2009) and according to the 2013 AKG the adequate daily iodine intake of Indonesian primary school children is $120 \mu \mathrm{g} /$ day (Ministry of Health, 2013). However, the impact of preventing iodine deficiency is prioritized because it can prevent the occurrence of poor cognitive decline compared to the effects of excess iodine intake (Campbell et al., 2012). Globally, efforts to reduce iodine deficiency in vulnerable populations such as school children and pregnant women are a public health problem that is still being faced.

The results of this study indicate that there is a relationship between iodine intake with the academic ability of elementary school children. This academic ability can be seen from several indicators and one of them is the result of midterm exam grades for elementary school children. Elementary school children who have adequate iodine 
intake can increase 18.9 units of math grade ( $b=0.02 ; 95 \% \mathrm{CI}=0.01$ to $0.02 ; \mathrm{p}=0.013$ ).

This is in line with a study by Wolka et al. (2014) shows that school children who do not have iodine deficiency have better academic abilities compared to those who are deficient despite taking into parental education and also school attendance. School children who are given iodine capsule supplementation also have better mental performance for their school academics (Faught et al., 2017).

The mean iodine intake of primary school children in this study was $134.50 \mu \mathrm{g} /$ day with the lowest intake being $12.7 \mu \mathrm{g} /$ day and the highest intake was $427.56 \mu \mathrm{g} /$ day. When compared with the needs of the 2013 NAR, the intake level is adequate. A study by Andersson et al. (2019) showed that the tendency of primary school children iodine intake from year to year in Switzerland has increased to be adequate with the efforts of iodine supplementation in household salt, but in pregnant women still experience low iodine intake.

A study by Prangthip et al. (2019) reported that school children who consumed a balanced nutritional intake had better academic performance in terms of examinations, attendance of school attendance and were able to do schoolwork better than children who consume diets whose nutritional intake was not balanced. This shows that the optimal and balanced nutrition intake between macro and micro especially iodine a improved the academic achievement of school children.

\section{The relationship between iron in- take and math achievement in pri- mary school children}

In developing countries, there are many cases of children suffering from malnutrition and iron nutritional anemia as well as conditions where micronutrient intake is lower than recommended (Desai et al., 2015). Deficiencies of some micronutrients such as iron neg- atively impact cognitive abilities and interfere with children's growth and development (Swaminathan et al., 2013).

Iron deficiency can occur if the population consumes a monotonous diet that has a high phytate content and low consumption of animal food sources (Thankachan et al., 2013). Iron can also be absorbed around 80$85 \%$ by the body into red blood cells if the presence of other micronutrients such as vitamin $\mathrm{A}$, vitamin $\mathrm{B} 2$, vitamin $\mathrm{B} 12$, vitamin $\mathrm{C}$ and folic acid in optimal conditions to form hemoglobin (Semba and Bloem, 2002).

Iron affects children's cognitive during elementary school which can affect morbidity and adversely affects classroom attention and academic performance and both of these can destroy performance in school processes and academic grades (Fiorentino et al., 2018).

The child's optimal cognitive abilities help assimilate and process information obtained from various sources and turn it into knowledge. Cognitive is included in the process of learning, concentration, memory, language, ability to think, ability to count and make decisions (Monti et al., 2015).

The present study shows that iron intake has an indirect relationship in improving the academic achievement. Christian et al. (2011) showed that iron did not have a positive effect on cognitive and academic achievement. However, a study by Luo et al. (2017) reported that low iron intake inhibited academic achievement and cognitive. A study in Denmark also reported that female students aged 8-11 years with low iron intake showed poorer academic achievement than those with high iron intake (Sorensen et al., 2015).

3. The relationship between zinc intake and math achievement in primary school children

Micronutrient deficiency is the most common condition in developing countries, especially in the age group of school children caused by the high physiological need in the process of 
growth and development but low consumption of foods rich in nutrients (Díazet al., 2003).

Zinc is a micro nutrient that plays an important role in the growth and development of school children and affects cognitive function (Annan et al., 2019). Zinc is included as the second most important mineral after iron in the body (Kambe et al., 2015). Zink contributes to the function of more than 2000 proteins, plays a role in many cellular mechanisms, DNA synthesis, protein synthesis, wound healing, immunity and cognitive function (Portbury and Adlard, 2017).

Zinc deficiency affects the academic ability of school children because it causes disturbances in neuropsychological behavior, changes emotional behavior, decreases spontaneous activity, disturbs memory, interferes with concentration and learning ability (Pongcharoen et al., 2011).

Therefore, maintaining zinc levels in homeostatic conditions by consuming a balanced diet is highly recommended for optimal physiological function (Portbury and Adlard, 2017). In the central nervous system, maintenance of intake and zinc levels is very important in brain health, especially cognitive function (Nuttall and Oteiza, 2014). However, the effect of zinc on the cognitive and academic performance of school children still experiences inconsistent results (Annan et al., 2019).

This study showed that zinc intake has an indirect relationship in improving the academic ability of elementary school children $(b=0.17 ; 95 \% \mathrm{CI}=-0.01$ to $0.36 ; \mathrm{p}=$ 0.056). In this study the study subjects came from rural areas that have families with low socioeconomic status and parental education, which on average only at the first level. The results of this study are in line with Pongcharoen et al. (2011), which shows that children who have adequate long-term zinc intake from infancy to 9 years do not even have an effect on IQ and school academic performance. That is caused by the average child who is the subject of study comes from low socioeconomic, low parental education, and the background work of parents who are mostly farmers and laborers, as well as experiencing other nutrient deficiencies.

The benefits of zinc intake will provide optimal function in the cognitive of school children with the support of various factors such as other nutrients, health status, and socioeconomic factors (Walker et al., 2007). What enables Zink's function on children's cognitive and academic schools not to have a good effect is the interaction of other nutritional deficiencies such as iodine, folic acid, vitamin B-12, omega 3 , unsaturated fats (Huang et al., 2017).

\section{AUTHOR CONTRIBUTION}

Romiza Arika was responsible for all the scientific content of the article, data analysis and interpretation, drafted manuscripts and made revision. Sapja Anantanyu provided suggestion. Yulia Lanti Retno Dewi provided guidance from the conceptual framework, data analysis to discussion.

\section{CONFLICT OF INTEREST}

There is no conflict of interest in this study.

FUNDING AND SPONSORSHIP

This study is self-funded.

\section{ACKNOWLEDGMENT}

Our gratitude goes to Pakis community health centers, Warangan 2, Gumelem, Sobowono, and Kenalan primary schools which given permission and help during the data collection.

\section{REFERENCE}

Allen A, Allen S, Rodrigo R, Perera L, Shao W, Li C, Premawardhena A (2017). Iron status and anaemia in Sri Lankan 
Arika et al./Micro Nutrients Intake and Math Achievement in Primary School

secondary school children: A crosssectional survey. PLos One, 12(11).

Andersson M, Hunziker S, Fingerhut R, Zimmermann MB, Herter-Aeberli I (2019). Effectiveness of increased salt iodine concentration on iodine status: Trend analysis of cross-sectional national studies in Switzerland. Eur J Nutr.

Andersson M, Karumbunathan V, Zimmermann MB (2012). Global iodine status in 2011 and trends over the past decade. J Nutr. 142(4): 744-750.

Annan RA, Apprey C, Asamoah-Boakye O, Okonogi S, Yamauchi T, Sakurai T. (2019). The relationship between dietary micronutrients intake and cognition test performance among school-aged children in government-owned primary schools in Kumasi metropolis, Ghana. Food Sci Nutr; 7(9): 3042-3051.

Arnold LE, DiSilvestr RA (2005). Zinc in attention-deficit/hyperactivity disorder. J Child Adolesc Psychopharmacol; 15(4): 619-627.

Bath SC, Steer C, Golding J, Emmet P, Rayman MP. (2013). Effect of inadequate iodine status in UK pregnant women on cognitive outcomes in their children: results from the Avon Longitudinal Study of Parents and Children (ALSPAC). Lancet: 382(9889): 331337.

Beckford K, Grimes CA, Margerison C, Riddell LJ, Skeaff SA, Nowson CA (2017). Iodine intakes of victorian school children measured using 24-h urinary iodine excretion. Nutrients; 9(9): 1-11.

Benton D (2010). The influence of dietary status on the cognitive performance of children. Mol Nutr Food Res; 54(4): 457-470.

Bougma K, AboudFE, Harding KB, Marquis GS (2013). Iodine and mental development of children 5 years old and under: A systematic review and metaanalysis. Nutrients; 5(4): 1384-416.

BPS KM. (2018a). Kecamatan pakis dalam angka 2018.

BPS KM (2018b). Statistik daerah Kabupaten Magelang 2018 (Statistics of the district of Magelang in 2018).

Bryan J, Osendarp S, Hughes D, Calvaresi E, Baghurst K, Klinken JW (2004). Nutrients for Cognitive Development in School-aged Children. Nutr Rev; 62(8): 295-306.

Campbell NRC, Dary O, Cappuccio FP, Neufeld LM, Harding KB, Zimmermann MB (2012). Need for coordinated programs to improve global health by optimizing salt and iodine intake. Rev Panam Salud Publica; 32(4): 281-286. Carvalho AC, Machado A, Embalo AR, Bordalo AA (2018). Endemic goiter and iodine deficiency status among GuineaBissau school-age children. Eur J Clin Nutr, 72(11): 1576-1582.

Chen W, Li X, Wu Y, Bian J, Shen J, Jiang W, Zhang W (2017). Associations between iodine intake, thyroid volume, and goiter rate in school-aged Chinese children from areas with high iodine drinking water concentrations. Am J Clin Nutr, 105(1): 228-233.

Christian P, Morgan ME, Murray-Kolb L, LeClerq SC, Khatry SK, Schaefer B, Tielsch JM (2011). Preschool iron-folic acid and zinc supplementation in children exposed to iron-folic Acid in utero confers no added cognitive benefit in early school-age. J Nutrition; 141(11): 2042-2048.

Desai IK, Kurpad AV, Chomitz VR, Thomas T (2015). Aerobic fitness, micronutrient status, and academic achievement in Indian school-aged children. PLos One; 10(3).

Díaz JR, De las Cagigas A, Rodríguez R (2003). Micronutrient deficiencies in 
Arika et al./Micro Nutrients Intake and Math Achievement in Primary School

developing and affluent countries. Eur J Clin Nutr; 57(1): S70-S72.

Eilander A, Gera T, Sachdev HS, Transler C, Cm Van Der Knaap H, Kok FJ, Osendarp SJ (2010). Multiple micronutrient supplementation for improving cognitive performance in children: systematic review of randomized controlled trials 1-3. Am J Clin Nutr; 91: 115-145. Emder PJ, Jack MM (2011). Iodine-induced neonatal hypothyroidism secondary to maternal seaweed consumption: A common practice in some Asian cultures to promote breast milk supply. JPaediatr Child Health; 47(10): 750752.

Faught EL, Montemurro G, Storey KE, Veugelers PJ (2017). Adherence to dietary recommendations supports Canadian children's academic achievement. Can J Diet Pract Res; 78(3): 102108.

Fiorentino M, Perignon M, Kuong K, De Groot R, Parker M, Burja K, Wieringa FT (2018). Effect of multi-micronutrient-fortified rice on cognitive performance depends on premix composition and cognitive function tested: Results of an effectiveness study in Cambodian school children. Public Health Nutr; 21(4): 816-827.

Ford TC, Downey LA, Simpson T, McPhee G, Oliver C, Stough C (2018). The effect of a high-dose vitamin $\mathrm{b}$ multivitamin supplement on the relationship between brain metabolism and blood biomarkers of oxidative stress: A randomized control trial. Nutrients; 10(12).

Gordon RC, Rose MC, Skeaff SA, Gray AR, Morgan KMD, Ruffman T (2009). Iodine supplementation improves cognition in mildly iodine-deficient children. Am J Clin Nutr; 90(5): 1264-1271.

Hess SY, Lönnerdal B, Hotz C, Rivera JA, Brown KH (2009). Recent advances in knowledge of zinc nutrition and human health. Food Nutr Bull; 30(1): S5-11.

Hirano T, Murakami M, FukadaT, Nishida K, Yamasaki S, Suzuki T (2008). Roles of zinc and zinc signaling in immunity: Zinc as an intracellular signaling molecule. Adv Immunol; 97: 149-176.

Huang G, Mei X, Hu J (2017). The Antioxidant Activities of Natural Polysaccharides. Curr Drug Targets; 18(11).

Kambe T, Tsuji T, Hashimoto A, Itsumura N (2015). The physiological, biochemical, and molecular roles of zinc transporters in zinc homeostasis and metabolism. Physiol Rev; 95(3): 749-784.

Kartika DS, Rahardjo SS, Murti B (2019). Multilevel analysis on the contextual effects of hygiene, environmental sanitation, and diarrhea prevention in elementary school students in Ngawi, East Java. J Epidemiol Public Health, 4(2): 97-108.

Kim JY, Kang SW (2017). Relationships between dietary intake and cognitive function in healthy Korean children and adolescents. J Lifestyle Med;7(1): 10-17.

Koukkou EG, Roupas ND, Markou KB. (2017). Effect of excess iodine intake on thyroid on human health. Minerva Med;108(2): 136-146.

Luo R, Yue A, Zhou H, Shi Y, Zhang L, Martorell R, Sylvia S (2017). The effect of a micronutrient powder home fortification program on anemia and cognitive outcomes among young children in rural China: A cluster randomized trial. BMC Public Health. 17(1): 738.

Ministry of Health RI. Peraturan Menteri Kesehatan RI No. 75 Tahun 2013 Tentang Angka Kecukupan Gizi yang Dianjurkan untuk Bangsa Indonesia. Pub L; 75(1).

Monti JM, Moulton CJ, Cohen NJ (2015). The role of nutrition on cognition and 
brain health in ageing: A targeted approach. Nutr Res Rev; 28(2): 167-180.

Murcia M, Espada M, Julvez J, Llop S, Lopez-Espinosa MJ, Vioque J, Rebagliato $M$ (2018). Iodine intake from supplements and diet during pregnancy and child cognitive and motor development: the INMA Mother and Child Cohort Study. J. Epidemiol. Community Health; 72(3): 216-222.

Nuttall JR, Oteiza PI. (2014). Zinc and the aging brain. Genes Nutr; 9(1): 379.

Pongcharoen T, DiGirolamo AM, Ramakrishnan U, Winichagoon P, Flores R, Martorell R (2011). Long-term effects of iron and zinc supplementation during infancy on cognitive function at $9 \mathrm{y}$ of age in northeast Thai children: a follow-up study. Am J Clin Nutr; 93(3): 636-643.

Portbury SD, Adlard PA (2017). Zinc signal in brain diseases. Int JMol Sci; 18(12).

Prangthip P, Soe YM, Signar JF (2019). Literature review: nutritional factors influencing academic achievement in school age children. J Adolesc Med Health. https://doi.org/10.1515/ijamh2018-0142.

Prasad AS (2013). Discovery of human zinc deficiency: Its impact on human health and disease. Adv Nutr; 4(2): 176-190.

Pratiwi DI, Tamtomo D, Murti B (2019). Is cognitive impairment a risk factor for post-stroke depression? A meta-analysis study. J Epidemiol Public Healt; 4(2): 81-87.

Purnamasari DU, Dardjito EK (2015). Analysis of iodium deficiency disorders status and health aspects which related to achievement study at primary school children in IDD endemic areas. Kesmasindo; 7(2): 71-81.

Semba RD, Bloem MW (2002). The anemia of vitamin a deficiency: Epidemiology and pathogenesis. Eur J Clinl Nutr;
56(4): 271-281.

Soleimani N, Abbaszadeh N (2011). Relationship between anaemia, caused from the iron deficiency, and academic achievement among third grade high school female students. Procedia Soc and Behav Sci; 29: 1877-1884.

Sorensen LB, Damsgaard CT, Dalskov SM, Petersen RA, Egelund N, Dyssegaard CB, Lauritzen L (2015). Diet-induced changes in iron and n-3 fatty acid status and associations with cognitive performance in 8-11-year-old Danish children: Secondary analyses of the optimal well-being, development and health for danish children through a healthy new nordic diet school meal study. Br J Nutr; 114(10): 1623-1637.

Stiles J, Jernigan TL (2010). The basics of brain development. Neuropsychol Rev; 20(4): 327-348.

Swaminathan S, Edward BS, Kurpad AV (2013). Micronutrient deficiency and cognitive and physical performance in Indian children. Eur J Clin Nutr; 67(5): 467-474.

Thankacha P, Selvam S, Surendran D, Chellan S, Pauline M, Abrams SA, Kurpad AV (2013). Efficacy of a multi micronutrient-fortified drink in improving iron and micronutrient status among schoolchildren with low iron stores in India: A randomised, double-masked placebo-controlled trial. Eur JClin Nutr; 67(1): 36-41.

Walker SP, Wachs TD, Meeks Gardner J, Lozoff B, Wasserman GA, Pollitt E, Carter JA (2007, January 13). Child development: risk factors for adverse outcomes in developing countries. Lancet; 369(9556):145-157.

Wang X, Hui Z, Dai X, Terry PD, Zhang Y, Ma M, Zhang B (2017). Micronutrientfortified milk and academic performance among Chinese middle school stu- 
Arika et al./Micro Nutrients Intake and Math Achievement in Primary School

dents: A cluster-randomized controlled trial. Nutrients; 9(3).

Wilson M, Hogstrand C, Maret W (2012). Picomolar concentrations of free zinc (II) ions regulate receptor protein-tyrosine phosphatase $\beta$ activity. J Biol Chem; 287(12): 9322-9326.

Wolka E, Shiferaw S, Biadgilign S (2014). The effect of iodine-deficiency disor- ders on academic achievement of school children in Southern Ethiopia. Public Health Nutr; 17(5): 1120-1124.

Zicof E, Sri Rahardjo S, Murti B (2018). Multilevel analysis: Biopsychosocial determinants and environmental factor on the incidence of diarrhea among children under five in Surakarta. J Epidemiol Public Health, o3(3): 323-330. 